\title{
American cities, global networks: mapping the multiple geographies of globalization in the Americas
}

\author{
Cidades americanas, redes globais: mapeando as múltiplas \\ geografias da globalização nas Américas
}

Noah Toly ${ }^{[0]}$, Sofie Bouteligier ${ }^{[b]}$, Graham Smith ${ }^{[\mathrm{d}}$, Ben Gibson ${ }^{[d]}$

[a] Director of Urban Studies and associate professor of Politics \& International Relations, Wheaton College, Wheaton - USA, e-mail: noah.toly@wheaton.edu

[b] Postdoctoral Researcher, Environmental Policy Group, Wageningen University, Wageningen - Netherlands, email: sofie.bouteligier@wur.nl

[c] Hastert Scholar, Wheaton College, Wheaton - USA, e-mail: graham.smith@my.wheaton.edu

[d] Hastert Scholar, Wheaton College, Wheaton - USA, e-mail: ben.gibson@my.wheaton.edu

\begin{abstract}
The mapping of advanced producer and financial service firms across global cities began to increase understanding of the role of cities in global governance, the presence and influence of cities in the shifting architecture of global political economy, and the role of globalization in shaping the landscape of local and regional governance. The literature that emerged from such studies has also emphasized 1) increasing levels of inequality in global cities and 2) attendant contests over local outcomes of globalization while seeking other ways of measuring and articulating the emergence of globalizing cities. Analyzing location strategies in other sectors can speak to these issues. This paper extends methodology common to the global cities literature to map non-governmental organization (NGO) and energy corporation offices in the Americas, focusing on the convergence and divergence of these networks with those of advanced producer and financial services firms. Mapping all three sectors might reveal multiple geographies of globalization in the Americas. Because globalizing cities have become the centers of integrated world capital, radical poverty, and environmental injustice, studies of poverty in the Americas must take seriously the urban centers that increasingly have become the hub of economic and ideological flows. The urban location strategies of advanced producer and financial services, global NGOs, and global energy corporations must be understood in order to grapple more fully with issues of inequality in American cities.
\end{abstract}

Keywords: Globalization. Cities. Governance. The Americas.

\section{Resumo}

O mapeamento de firmas de produção avançada e empresas de serviços financeiros em cidades globais proporciona um aumento na compreensão do papel das cidades na governança global, a presença e a influência das 
cidades na estrutura mutante da economia política global, e o papel da globalização na formação do cenário de governança local e regional. A literatura que surgiu a partir de tais estudos também enfatizou: 1) aumento dos níveis de desigualdade em cidades globais e 2) subsequente concorrência sobre os resultados locais da globalização, buscando outras formas de medir e articular o surgimento de cidades globalizantes. A análise de estratégias de localização em outros setores pode corroborar essas questões. Este artigo estende a metodologia comum da literatura sobre cidades globais para mapear escritórios de organizações não governamentais (ONGs) e empresas de energia nas Américas, com foco na convergência e divergência dessas redes com as de firmas de produção avançada e empresas de serviços financeiros. O mapeamento dos três setores pode revelar múltiplas geografias da globalização nas Américas. O fato de as cidades da globalização tornarem-se os centros do capital mundial integrado, da pobreza radical, e da injustiça ambiental, exige que os estudos sobre a pobreza nas Américas levem a sério os centros urbanos que se caracterizam cada vez mais como nós dos fluxos econômicos e ideológicos. As estratégias de localização urbana de produção avançada e serviços financeiros, ONGs, e empresas globais de energia devem ser entendidas a fim de serem mais relacionadas com questões de desigualdade nas cidades americanas.

Palavras-chave: Globalização. Cidades. Governança. Américas.

\section{Introduction}

The relationship among poverty, governance, and social movements in the Americas cannot be fully grasped apart from understanding the idiosyncrasies of contemporary American urbanism and its relationship to global processes. The partial denationalization of global politics has been accompanied by the increasing importance of non-state and subnational state actors - including non-governmental organizations (NGOs), multi-national corporations, and city governments (CASTELLS, 2005). It has further resulted in the rising significance of cities as sites in and for global governance (BRENNER, 1998; SWYNGEDOUW, 2004). Cities serve as sites for scalejumping - the movement of organizations and issues across scalar boundaries (GLASSMAN, 2002) - and locales for networking. Global actors, by concentrating in cities, take advantage of propinquity and the dense networks available in the urban landscape, and in doing so, also establish certain cities as "nodes" in their global networks (CASTELLS, 2000b).

In contrast to the idea that a revolution in communication, information, and transportation technologies has brought the demise of geography - see Graham (1998) for a review of the literature embracing this position -, the literature on "global cities" or "world cities", those urban agglomerations more or less directly articulated to a shifting architecture of global political economy (SASSEN,
1991; TAYLOR, 2004b), suggests the continued role of particular locales as governance centers with increasingly global scope. Since John Friedmann (1986) formulated his "world cities hypothesis", many have tried to measure manifestations of the phenomenon that Richard Florida attempts to capture with his suggestion that "the world is spiky" (FLORIDA, 2005, 2008) - that, in fact, globalization has had disparate effects across cities and that some cities play special roles concerning connectivity to other locales through global networks or strategic location in global networks. Many of these attempts have emphasized the disproportionate concentration of advanced producer and financial services firms in particular types of cities (e.g. publications of the Global and World Cities Research Network at Loughborough University).

This paper extends methodology common to the global cities literature to map non-governmental organization (NGO) and energy corporation offices. Global NGOs represent the cutting edge of global politics; their office location strategies may reveal what locations are strategic for regional and global political developments. Global energy corporations shape the economic and environmental landscapes of the world - consider the 2010 BP oil spill in the Gulf of Mexico. In particular, this paper will focus on the convergence and divergence of these networks with those of advanced producer and financial services firms in the Americas. Doing so will provide a 
more robust picture of what functions certain cities play in the Americas, why organizations are drawn to those locales, and how it is that American cities may be characterized by the "production of presence", to use a term coined by Saskia Sassen (2006). Mapping all three sectors might reveal whether each sector interacts with or deals with the effects of the others. Because globalizing cities have become the centers of integrated world capital, radical poverty, and environmental injustice, studies of poverty in the Americas must take seriously the urban centers that increasingly have become the hub of economic and ideological flows. The urban location strategies of advanced producer and financial services, global NGOs, and global energy corporations must be understood in order to grapple more fully with issues of inequality in American cities.

After a brief review of relevant literature, including special emphasis upon previous findings on the role of American cities, the article presents our methodology, results, and conclusions. In the end, the article contributes to a more robust understanding of American cities' position in global networks as well as the context of, challenges for, enduring obstacles to governance from below in the cities of the Americas.

\section{Global cities research, its critiques and its view on American cities}

The increasing concern for understanding the presence and influence of the city in the world has emerged alongside increasing interest in questions of both local and global governance. Governance, the exercise of influential, effective, and sometimes decisive authority, is distinct from government, the exercise or locus of formal or legitimate authority. Investigations into the relevance of this concept for global and local politics have resulted in the proliferation of actors and sites regarded as relevant to political economic outcomes at multiple scales. At the local level, where municipalities enjoy formal authority, a raft of actors (e.g. private corporations, special authorities, booster clubs, and others) is recognized to enjoy informal, but still effective, authority. At the global level, while formal authority is absent, formal authorities - namely, states - have constituted the most studied and highly regarded actors in the determination of global politico-economic outcomes. States act at the global level by projecting formal and more or less legitimate domestic authority enjoyed by dint of territorial sovereignty. At the same time, however, numerous other actors influence the same outcomes over which states traditionally have held influence. These actors include transnational corporations and transnational activist organizations, among others.

A great part of the literature on the presence and influence of cities in the world is concerned with cities as strategic sites for the location of other actors involved in global governance (CALDER; DE FREYTAS, 2009), sites in and from which global corporations and activist organizations (TAYLOR, 2004a) project their effective influence over global affairs. This literature had its origins in the concerns of world systems theory - the term "world cities" was coined in part for its fitness to a world systems approach to the study of global political economy - and is preoccupied with both describing the relationship between the urban and the global and articulating an understanding of the roles in which different cities find themselves. Many of the most prominent studies of world cities have focused on the role of cities as command and control centers in the global economy, locales exhibiting a disproportionate concentration of advanced producer and financial services firms that coordinate the activity of materially and geographically dispersed, but still socially concentrated, capital (SASSEN 1991; TAYLOR, 2004b). Others have augmented this approach by studying, for example, the cultural capital of cities (KRÄTKE, 2004). Still, the chief mechanism for determining the status of a given city - "World city? Or not?" - has been the observation of office locations for advanced producer and financial services firms.

Since this paper deals with cities in the Americas, the mega-city concept is worth mentioning as well. According to the UN definition, mega-cities are urban areas with more than ten million inhabitants (UN-HABITAT, 2006). For 2009, the UN identified 21 mega-cities. Four are located in Latin America, two in North America. Furthermore, Latin America has four cities with a population between five and ten million (UNDESA, 2010). The mega-city concept has triggered debates, especially because the majority of these cities are located in the developing 
world, meaning the term is often charged with negative connotations. Sassen, for example, states that the "mega-city syndrome" - the burden of population size and the related problems - acts as a barrier for developing cities as they display the processes she describes and attempt to fulfill the role of global cities (SASSEN, 2000). Parnreiter (2009) has criticized the literature for not conducting a more comprehensive analysis of mega-cities' challenges and claims that we need to conceptualize these cities as "gateway cities in current processes of globalization". Castells goes even further and attributes specific functions to mega-cities and conceptualizes them as the cities of the future. Their significance is not so much linked to their size, but to the concentration of higher functions in the scope of politics, economy, information networks and culture. Mega-cities are conceived as the main centers, the connecting points in the global political, economic, informational and cultural networks of the $21^{\text {st }}$ century (BORJA; CASTELLS, 1997; CASTELLS, 2000b). With this statement, Castells transforms the mega-city from a form (a city with at least 10 million inhabitants) into a process (the linking up of a place to a global network), a movement that has been criticized. According to Taylor (1999), there are no credible processes that turn mega-cities in the Global South into future centers of wealth and power and, furthermore, the rise of East Asian cities cannot be extrapolated to other cities in the developing world. He emphasizes that global cities and mega-cities have different urban problems in origin and type. Castells's space of flows and his elaboration on mega-cities only has value for Taylor in so far that it creates new insights for understanding the core and periphery of the current world-system.

The established approach to global cities measurement understands the techno-material aspects of globalization to be either of utmost importance or, at the very least, of measurable significance. Casting the gaze of transnational urbanism upon a small group of 50-150 cities, this literature has not only listed cities with disproportionate concentrations of advanced producer and financial services firms, but has also ranked cities according to the intensity of their connectivity - usually accomplished by discerning the connections between offices in different cities or the strategic importance of a given officecity node in a firm's overall network (TAYLOR et al.,
2010). In so doing, this literature has advanced an understanding not only of world cities, but also of world city networks, the circuits in which certain cities play an important role.

Still, several significant objections to this approach have emerged from scholars concerned with appropriately understanding both the urban landscape and the role of the city/cities in the global landscape. This approach has emphasized the condition of economic "globality" - to use Manfred Steger's (2002) distinction between globality, or interconnectedness; globalization, or the process leading to increasing interconnection; and globalism, or the increasing awareness of a world community as the point of reference or context for social relations - at the expense of the processes of globalization or the political, cultural, or ecological aspects of globalization. In addition, Short (2004) identified three problem areas in world/global cities research. First, there is, what he calls, "the dirty little secret of world cities research" (SHORT et al., 1996): a lack of good quality and international comparable data on cities. As a consequence, researchers use proxy-data, which triggers discussion over validity. Furthermore, once scholars move beyond the key global cities, there is no consensus on rankings (DERUDDER, 2006). Second, research traditionally focused on a limited number of world city functions and as a result directed its focus to a small group of cities at the top of world city rankings. In response to this, Short et al. (2000) stress the need to look at all cities as "gateways for globalization". Third, world/global cities research searches for evidence of global connectivity - thus increasing the risk that attention is limited to those cities that seem to confirm theoretical assumptions (JAYNE, 2004) - while identifying a lack of connectivity is of equal importance to understanding the role of cities in globalization and might highlight the "black holes" and "loose connections" in global networks.

Robinson's (2002, 2006) objection towards world and global cities research is even more fundamental. She doubts the virtues of denoting "global cities" or devising systems for categorizing and ranking such cities, especially when the criteria to do so are based on the experience of just a few (ROBINSON, 2006). As Robinson (2006) has noted, there are a myriad of ways in which globalization affects various urban landscapes, some of which 
cannot be captured by methodologies popularized by Beaverstock (1999), Taylor (2004b) and others. Robinson recognizes that all cities are ordinary cities, experiencing the process of globalization in idiosyncratic ways. Her critique is particularly effective at a time when many urbanists are abandoning talk of "the city", in favor of "cities", deemphasizing the commonalities of a generic urban experience and emphasizing the distinctive, often unique, characteristics of urban life in particular cities. The need to avoid ethnocentricity - the idea that all cities will follow the trajectory of global cities in the West has also been stressed (SHATKIN, 2007). And Hill (2004) asks more attention for cities' "nested configurations" - their histories, institutional set-ups, ideologies and political projects. In sum, critics state that a more inclusive and nuanced approach towards globalizing cities will extend our understanding of cities' experiences and will stimulate further theorizing on how globalization takes place (SHORT, 2004).

This study is sympathetic to the critiques leveled against some of the global cities literature. In some ways, this sympathy should cause us to bristle at the use of the terms, "global city", "world city", and the like, to avoid advancing such notions, and certainly not to proliferate such distinctions. We should remember, however, to distinguish between the condition of urban globality and the relationships between various urban areas and the processes of globalization. Such a distinction is necessary to proceed beyond the quantitative nature of the methodology employed throughout this study. Furthermore, sensitivity to such critiques has opened new lines of inquiry that do not abandon talk of global cities as much as they dis-place it. For example, Amen, Archer and Bosman (2006) have attempted to "relocate global cities" "from the center to the margins", studying the ways in which global and urban dynamics intersect in various cities that are, as Robinson $(2002,2006)$ puts it, "off the map" of much global cities research. Their work is not alone in this effort, as other researchers have undertaken to expand the number and type of global cities, rather than to abandon the term (GUGLER, 2004).

Though we believe that the methodology developed most fully by Beaverstock, Taylor and others is insufficient for a robust understanding of the presence and influence of cities in the world, we think still that the limits of the methodology, itself, have not been reached - and that it can reveal considerably more about the "spikiness" of the global urban landscape. While the explanatory power of this approach may be limited, it has not exhausted its usefulness in identifying cities that prove strategic to global governance and especially to understanding in which cities certain networks converge and in which cities those networks diverge. Such a developed understanding of the allocation of different networks and flows allows us to hold the approaches of Robinson and Taylor and colleagues in a dialectical tension with one another to advance the field of research. This requires the mapping of multiple networks using the same or similar methodologies, which promises to open up the measurement of various aspects of urban globality beyond the economic and to demonstrate the extent to which globalizing cities are experiencing a "production of presence" (SASSEN, 2006). Hitherto, most efforts so far have not used the same methodologies employed to measure the disproportionate concentration of advanced producer and financial services firms.

Attention to the role and position of American cities in the global cities literature has been thin. New York City has received a great deal of attention as one of the three cities that traditionally top the world/global cities rankings, leaving other North American cities in second-rate positions. Although several scholars have met this imbalance by studying producer and financial services in other North American cities' (SASSEN, 1995; TAYLOR; LANG, 2005), this research could be extended and the picture could become more nuanced by examining more types of global networks. With regard to the study of Latin American cities, scholars have pointed out the limited applicability of the global cities perspective. General critiques that have been mentioned before are of relevance here. Roberts, for example, pointed out how cities of the Global South - and thus Latin American cities - are under-emphasized and under-theorized in global cities research, aligning with some of Robinson's and Short's comments. Furthermore, traditionally the major Latin American cities were not seen as fulfilling truly global city roles (ROBERTS, 2005; TAYLOR, 2005). The most recent GaWC ranking (2008), however, points out that several intermediate North American cities and Latin American cities have 
climbed up the ranking, thus their importance is increasing and their roles are shifting. Comparing the convergence and divergence of contemporary global networks should therefore shed light on American cities' role and the dynamics that are at play. Furthermore, it will be interesting to confront American cities" position in the global "space of flows" with what is happening in the "space of places". The former refers to the global networks in which goods, services, information, and finance flow and in which it is possible to organize social practices simultaneously without geographical continuity (CASTELLS, 2000a). The latter relates to issues of inequality and the concrete reality of day-to-day life in cities, where "meaning, function, and locality are closely interrelated" (CASTELLS, 2000a, p. 14).

\section{Methodology}

Urban economic globality has been measured, and corresponding global cities have been identified, by mapping the office locations of advanced producer and financial service firms. The Globalization and World Cities Research Network, led by Taylor, undertook one of the first attempts to define, categorize, and rank global cities. In GaWC Research Bulletin 5 (1999), they derive their fundamental vision from the work of Sassen (1991, p. 126) in considering world cities as "postindustrial production sites". These sites of innovation in corporate services and finance have been essential to the recent restructuring of the world economy. The distinguishing feature of global cities is advanced producer services, which are highly concentrated in a limited number of leading cities with "a specific role in the current phase of the world economy" (SASSEN, 1991, p. 126). With the producer service firm as the basic unit of analysis, the Loughborough group ranked cities based on aggregating information on cities' provision of each of the four services (accountancy, advertising, banking, and law). They were able to produce the "GaWC Inventory of World Cities" based on three research stages: (1) finding the global competence of service firms in terms of their presence in cities; (2) uncovering the global service centers for a given service sector; (3) identifying world cities of different degrees of corporate service provision.
As mentioned, scholars in the global cities literature have begun to call into question whether this economic measurement is sufficient to determine the significance of cities in the global landscape. As Robinson (2006) observes, "For many poor, 'structurally irrelevant' cities, the significance of flows of ideas, practices and resources beyond and into the city concerned from around the world stands in stark contrast to these claims of irrelevance". Cities, otherwise largely ignored in studies of advanced producer and financial service firms, serve invaluable roles in these flows through other organizations. As this particular paper explores, studying global NGOs' and global energy corporations' geographies contributes to the understanding of globalizing cities' role and functioning.

To proceed in data collection for global NGOs and global energy corporations, an understanding was required of what data exists concerning these sectors already. First, with regard to global NGOs, a previous study done by Taylor (2004a) on the role of NGOs in the global cities network allowed us to replicate his methodology. Taylor did not focus solely upon the prevalence of these NGOs, but used what he calls the interlocking network model. He verified the activity value of NGOs in various cities by determining what type of offices the organizations have in each city. He then studied the cities' relative connectivity by examining the density of links to other cities. For Taylor, just like advanced producer and financial service firms, NGOs needed to have offices on at least three continents, to be categorized as "global" (TAYLOR, 2004a). Second, in relation to global energy corporations no data set existed, since there are no previous studies done on the role of global cities as strategic sites for the networks of energy corporations. As Taylor (2004a, p. 269) noted in his study of global NGOs, "the answer to this problem is not to rely on official statistics".

Thus, in order to form a data set for global energy corporations we took the methodological framework applied by Taylor in his research of advanced producer and financial service firms and used it to categorize which corporations could be regarded as "global". It is important to note that, in this paper, we do not consider the activity values of particular offices or the relative connectivity of cities in these networks. In order to overlay and compare maps and understand these networks, which is the 
purpose of this paper, we chose first to compare whole networks and single out the findings for the Americas.

For the global NGOs, we eventually arrived at a final list of 76 global NGOs for mapping and statistical testing. We added $30 \mathrm{NGOs}$ to the $74 \mathrm{NGOs}$ from Taylor's original list, applying Taylor's selection criteria. The websites of these 104 NGOS were scrutinized for information on the location of their offices and we determined whether they functioned as a single entity under a corporate office or as a dispersed collaboration of independent entities. We also communicated with organizations by email and telephone to confirm this information. We eliminated 21 NGOs from Taylor's original list and seven from the additional list due to either not having NGOs on at least three continents, not functioning as a single entity, or not having sufficient information available.

For the global energy corporations, we arrived at a final list of 33 energy corporations for mapping and statistical testing. The energy corporations were derived from a list of the top 100 energy companies in the world put out by the advising firm PFC Energy. Two other rankings that have been considered were Plunkett Research and Platts Top 250. Plunkett Research provides a comprehensive list of international energy corporations including oil, natural gas, energy, petroleum, electricity, utilities, and others. While the list is comprehensive, it may have proven to be too expansive and difficult to draw a select number of corporations from the overall list. It gives no rankings for the companies, making it difficult to determine which energy corporations ought to be selected from their list for an effective multinational study. Platts Top 250 rankings are based upon a combination of assets, revenues, profits, and return on capital invested for companies with over $\$ 2$ billion in assets.

The industries in the rankings include coal and consumable fuels, diversified utility, electric utility, exploration and production, gas utility, independent power producers, integrated gas and oil refining and marketing, and storage and transfer. Though it provides a comprehensive set of industries, it did not fully match the criteria for what we considered to be global energy corporations. $\mathrm{PFC}^{1}$ determines its annual rankings based upon the total market capital of the corporation annually. It includes energy sectors such as exploration and production, refining and marketing, integrated natural gas, oil, and coal, oil field services, and energy equipment. By drawing from this list of the 100 corporations with the highest market capital we were essentially assured of including all energy companies that could potentially qualify as global energy corporations. To be classified as a "global energy corporation", an energy company needed to have regional offices located on at least three continents (TAYLOR, 2004a). By similarly scrutinizing the websites of the 100 companies, we found in which cities individual companies had located significant offices (once again communicating with organizations by email and telephone to confirm the information). From the original list of 100 , we found 33 of the corporations had offices on at least three continents, while the rest either were limited to one or two continents or there was insufficient information to positively determine global locations.

With these lists of 76 global NGOs and 33 global energy corporations compiled, we then created two separate matrixes of city locations to determine the frequency of office locations. Within these matrixes, we marked the presence of an office in a city by putting a " 1 " in their intersecting cell. We then were able to add up the total number of offices present in each city. In order to avoid mapping cities with coincidental presence of global NGOs and global energy corporations, we decided to take the presence of more than five offices as a threshold. Of course, this is an artificial and pragmatic choice and when discussing results reference will be made to cities with less than six offices when useful for the analysis. For the global NGOs map, the maximum amount of offices located in one city was 33 . For the global energy corporations map the maximum amount offices located in one city was eighteen.

However, every attempt to capture global geographies should acknowledge that it only visualizes 'snapshots' of reality, since global networks are in

${ }^{1}$ PFC Energy was originally founded in 1984 and now keeps offices in major world cities including Beijing, Houston, Kuala Lumpur, Lausanne, Manama, Paris, and Washington, D.C. Focused on international trends in the energy industry and the potential for sustainable development, PFC provides long-term consultation to its clients. For more information, see: <http://www.pfcenergy.com/>. 
constant flux (GRANT; NIJMAN, 2002). The data that are at the basis of this paper's maps reflect the situation of June 2010. Map 1 visualizes the position of American cities in the global office networks of the selected NGOs. Map 2 shows which American cities are part of the global office networks of the selected energy corporations. Map 3 results from overlaying map 1 and 2 with the alpha cities as identified by the GaWC 2008 ranking. Map 3 thus shows the convergence and divergence of these maps by identifying which cities are part of one, two or all three of the discussed global networks. The findings that result from this mapping exercise are discussed in the following section.

\section{American cities in global city networks}

Map 1 shows presence of NGOs throughout the Americas. Significant NGO concentration (more than five offices) is considerably less than in Europe, Africa, and Southeast Asia. This confirms Taylor's (2004a) finding that only a limited amount of American cities rank amongst the top NGO cities.

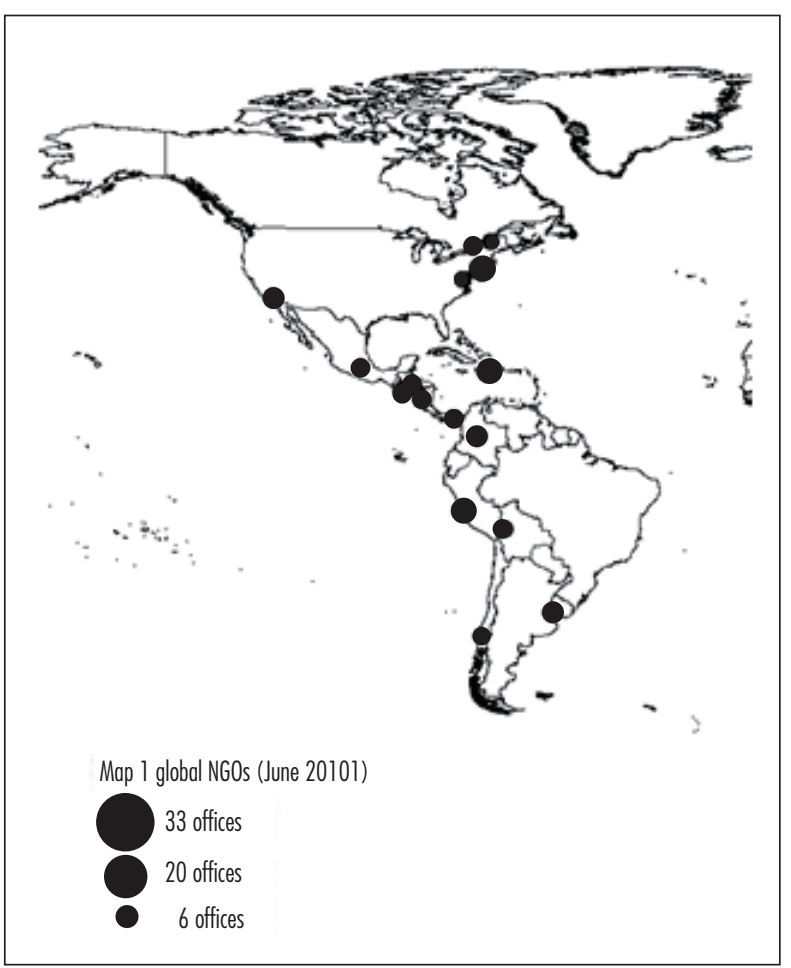

Map 1 - Global NGOs (June 2010)

Source: Research data.

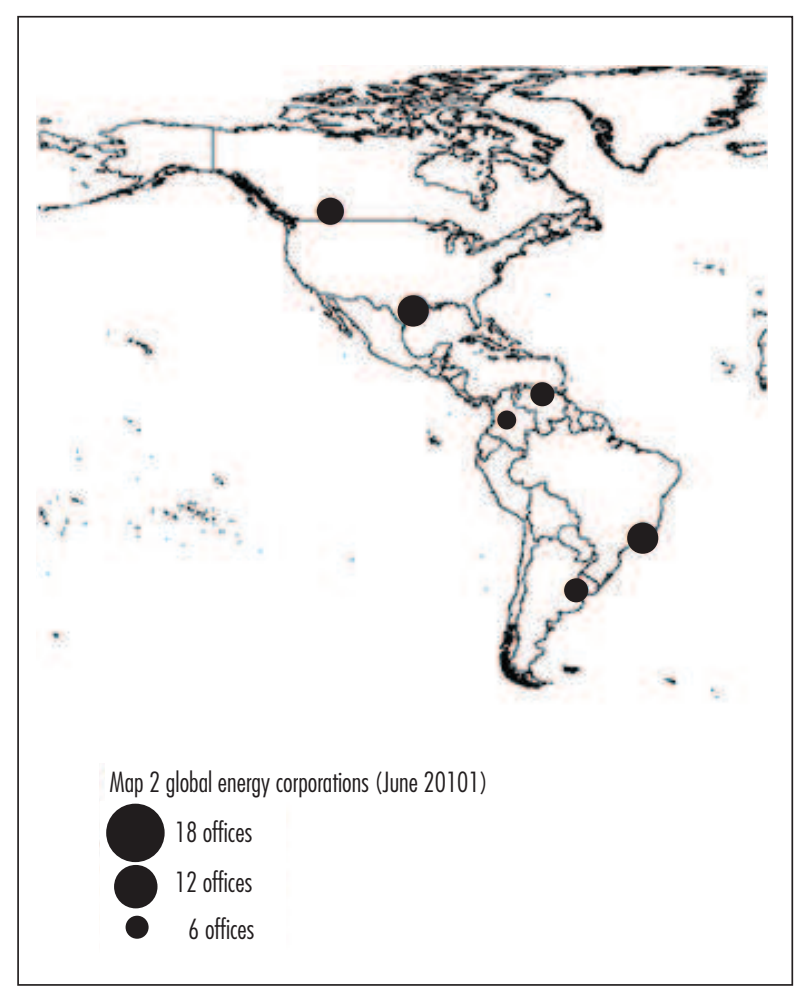

Map 2 - Global energy corporations (June 2010)

Source: Research data.

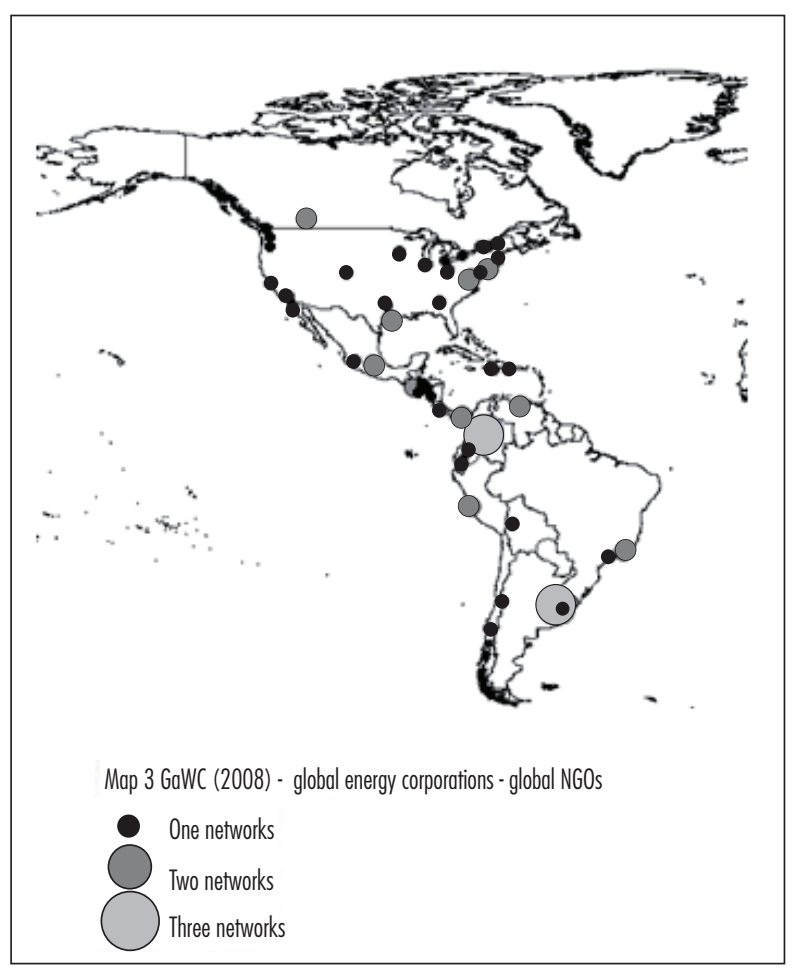

Map 3 - GaWC (2008), Global energy corporations - global NGOs Source: Research data. 
He identified Washington D.C., New York City, Mexico City, Santiago, and Buenos Aires as top 25 NGO cities (TAYLOR, 2004a), which are all on Map 1. Washington D.C. and New York City confirm their role as global political cities (ANHEIER et al., 2004; CALDER; DE FREYTAS, 2009; FOREIGN POLICY, 2008; UNION OF INTERNATIONAL ASSOCIATIONS, 2006). Key elements of global political cities are: (1) being a policy hub, (2) having a political-diplomatic community, and (3) functioning as a strategic information complex (CALDER; DE FREYTAS, 2009). Global political cities are thus seen as "relational incubators", meaning that they are places which enable complex exchanges between a variety of actors with a diversity of resources who may operate at different levels, but find each other in this particular place (NICHOLLS, 2008). According to Taylor (2004a), NGOs are attracted to such "loci of political power" rather than to economic nodes.

There is notably less global NGO presence in Latin America than in other developing regions, which might be explained by the fact that global NGOs reconfigure their networks according to where the need is highest (TOLY et al., 2012). The current geographies of global NGOs seem to focus less on Latin America and more on poorer regions in Africa and South Asia (BEBBINGTON, 2004, p. 739). It could also be that Latin American cities are marked by a more robust presence of domestic NGOs of relatively high capacity and, thus, that the demand for the presence of global NGOs is lower. Mexico City, Santiago, and Buenos Aires confirm their role of 'primate' city - a city where urbanization and economic and political processes are concentrated disproportionally in relation to the other cities in the same country.

Although Latin American primate cities have declined in favor of rapidly growing secondary centers (PORTES; ROBERTS, 2005), they still seem to be of significant importance in globalization processes (RODRIGUEZ; MARTINE, 2008). Two results are more surprising: first, there is substantial NGO presence in Central America, making these cities more connected to global civil society than they are to the global economy (BROWN et al., 2002). This confirms Taylor's (2004a) conclusion that global civil society creates a distinct global geography. Since Koch and Ruben (2007) have pointed out that Central American countries receive more NGO aid/capita than other Latin
American countries, the higher presence of these organizations in Central America thus seems to be a logical consequence. It also suggests that places in the Global South are part of NGOs transnational networks because these are the places where fieldwork needs to be done, whereas places in the Global North are of importance for network management (TAYLOR, 2005).

Second, expected presence in Brazil's major cities is not reflected on the map. Although São Paulo contains three NGO offices, it did not meet the sixoffice threshold, nor did Brasilia, which has five offices. In our data, only $17 \%$ of cities had five or more offices. With $56 \%$ of all NGO offices from our data set located in 84 cities worldwide - which is the total number of cities with more than five offices in our data set - it can be said that global NGOs' geography is characterized by a high concentration in a relatively small amount of cities (TOLY et al., 2012). The absence of any Brazilian city among these may be explained by a more complex urban system in Brazil (FREY et al., 2010). Rather than a monocentric or primate city system, Brazil's urban system is polycentric. Various cities - such as São Paulo, Rio de Janeiro, Brasilia, and Curitiba - possess the infrastructure, stability, and population to support a significant presence of global NGOs, which perhaps explains their diffusion in the country. Thus might emerge a specialization or division of labor between Brazilian cities, in which São Paulo has a disproportionate presence of economically powerful actors that might be relevant to some NGOs, while Rio de Janeiro and Brasilia have a disproportionate presence of national and global political clout that might be relevant to other NGOs.

With regard to location strategies of energy corporations, American cities have substantial presence. Out of the 25 cities that were initially identified as energy corporation centers - again indicating a high concentration in a small amount of cities Map 2 shows that six are located in the Americas, including three cities that rank in the top five (TOLY et al., 2012). Houston confirms its position as the "world's energy capital" (TAYLOR; LANG, 2005) and its success in surviving economic transformations (KATZ, 2009). The weight of the energy sector in Brazil (Rio de Janeiro) (VINE, 2005) and Calgary (TEPLOVA, 2006) is reflected too. Furthermore, the fact that also Buenos Aires, Caracas, and Bogotá are 
on the map mirrors Latin America's - and more concretely Argentina's, Venezuela's, and Colombia's importance to the energy sector (CASPARY, 2007; MANZANO; MORALDI, 2008). Besides, when we look at the cities in our data set that host less than six offices, the list of Latin American cities having energy corporation presence expands, adding cities like Lima, and Santa Cruz, each with four offices.

Map 3 shows unexpected results. There is not one North American city that is part of all three studied global networks. This seems to confirm that U.S. cities are generally less connected than European or Asia Pacific cities (TAYLOR; LANG, 2005), though it may also suggest that there is a sufficiently high level of infrastructural and organizational capacity in a sufficiently large and diverse set of cities that multiple networks need not organize in the same cities. However, it is still surprising that not one of the usually mentioned U.S. 'leaders' (New York City, Chicago, Los Angeles, Washington D.C., Miami) comes forth as a city that is part of diverse networks. It is the Latin American cities Bogotá, and Buenos Aires that are in this position. Furthermore, when we look at the cities that are part of two networks, New York City shares this position with Washington D.C., Houston, Mexico City, Rio de Janeiro, Caracas, Lima, and Guatemala City, cities that are usually conceptualized as second rate - or not mentioned at all in world/global cities rankings. This finding confirms the need to conduct more comprehensive research on the role of cities in processes of globalization. It also indicates that focusing on a few global cities primarily identified by the disproportionate presence of organizations from only one sector risks neglecting other significant developments. These three maps indicate that large cities and mega-cities in Latin America are strategic locations for global actors of various sorts.

\section{Global inclusion, local exclusion and inequality?}

The three maps showed that cities in the Americas are to a greater or lesser extent part of global networks of civil society and economic actors. Although some findings were unexpected in terms of which places are on and off the map, it is clear that cities in the Americas are significant for global actors. In both North America and Latin America, however, it is the 'usual suspects' that are included, thus strengthening the divide between these places and other urban centers. Also, scholars point out that even these supposedly new geographies reproduce and magnify existing patterns of inequality (ALDERSON et al., 2010) and leave Latin America in the same position as dependency and world-system research attributed to this region: integration in the world economy without an improvement of social well-being (GUILLÉN; SUÁREZ, 2005).

This inclusion in a global space of flows may also heighten local inequalities (JAMES, 2005). Global forces have led to a sharp competition between cities to attract global investment and strive for world/ global city status (DOUGLASS, 2002; UN-HABITAT, 2008). However, visionary plans to reach these goals often neglect the urban poor and marginalized and therefore exclude a large part of the population from the benefits linked to being part of global networks. Over and over again it is the Central Business Districts that are prioritized to experiment with ambitious economic, but also social and environmental policies (BRUGMANN, 2007), thus creating enclaves of well-being and further widening urban divides. The population in the Americas is highly urbanized: $82,1 \%$ of the North Americans, $71,7 \%$ of the Central Americans and $83,7 \%$ of the South Americans are urban dwellers. These numbers are comparable to the situation in Europe (between 67,7\% and 84,4\% urban population) and much higher than in Africa (between 23,7\% and 58,8\%) and Asia (between $32,2 \%$ and $66,3 \%$ ) (UN-HABITAT, 2008). Such a vast urban population asks for policies that address urban inequalities

The fact that cities in the Americas such as New York City, Los Angeles, Chicago, Mexico City, Buenos Aires, São Paolo, and Rio de Janeiro are in the top 30 cities in terms of contribution to the global GDP (UN-HABITAT, 2008) does not say anything about the living conditions of their inhabitants. High urban inequality is reflected in urban Gini coefficients of income and consumption disparities. Those of major metropolitan areas in North America (e.g. New York City and Washington D.C.) are comparable to the average Gini coefficients of some major cities in Latin America, which are traditionally categorized as having high urban inequality (UNHABITAT, 2008), with Bogota having the sharpest economic divide with a Gini coefficient above 
0.55. The Gini coefficients of Buenos Aires, Santiago and Mexico City are between 0.51 and 0.55 (UNHABITAT, 2008).

The reduction in poverty experienced in Latin American cities in the 1980s was not continued in the 1990s (UN-HABITAT, 2008). And although the social situation in many Latin American cities improved in the growth period between 2002 and 2006 , inequalities in the distribution of welfare and wealth remain high and the global financial crisis and the 2008 food crisis have reversed positive trends (OCAMPO, 2009; UN-HABITAT, 2008). The financial crisis had an impact on, for example, education, which is more visible in larger than in smaller cities (UN-HABITAT, 2008). The high food prices added another source of problems for the poorest residents (UN-HABITAT, 2008). Several scholars have pointed out that globalization processes impact local situations and that many global cities are divided cities, in which some enjoy the benefits of being included in global networks and others bear the costs (VAN KEMPEN, 2007). As Sassen has pointed out, today's global cities are home to both extreme luxury and extreme poverty, to both the hypermobile global elite and the immobile group of the local poor. This is because the postindustrial economy not only demands highly skilled people, but also a significant amount of workers with little education to fill old and new low-wage jobs (SASSEN, 1991). Thus, the concentration of global actors in major cities raises the question about the situation and living conditions of the less privileged who have few advancement possibilities (SASSEN, 1991). Further, the proximity of rich and poor families in many Latin American cities - although separated by the walls and fences of the gated communities - (ROITMAN; PHELPS, 2011) reflects the co-presence of the space of flows and the space of places.

However, it is not only global forces that are behind today's inequalities. It is important to pay attention to cities' histories, political, economic, and social situations in order to fully grasp how the presence of global actors and local developments interact with each other. Cities are now a "dynamic interface where state, international organizations, NGOs and the poor interrelate" (ROBERTS, 2005, p. 121). The Americas have been highly urbanized already for decades, thus some challenges are the result of past developments and policies. In Latin America, for example, 30 million people have moved out of slum conditions since 2000, but the total number of slum dwellers remains high. In Brazil and Argentina between 30 and $40 \%$ of the urban population still lives in slums, in Bolivia and Peru the amount even exceeds $40 \%$ (UN-HABITAT, 2008). Strong economic and social policies that address incomes of poor households and take into account persistently high rates of rural-urban migration are needed to address such a massive problem.

\section{Conclusion}

The role and position of American cities in global cities literature has been ambiguous: New York City has received the highest levels of attention, thus keeping other major North American cities out of the picture, and the large Latin American cities were not seen as fulfilling truly global city roles because the "mega-city syndrome" hinders them in this regard. However, our findings suggest that American cities are part of global networks of economic and civil society actors. Mainly it is the 'usual suspects' that are included, but there were also some unexpected results. First, Central American cities, often neglected in global cities research, are much more connected to global civil society than they are to the global economy. Second, NGO concentration is disproportionately low. Third, not one North American city is part of all three studied global networks.

Work on poverty, governance, and social movements in the Americas must confront the relative connectedness of some American cities to the space of flows and issues of inequality in the space of places. In attempts to be the most attractive place for global investment and in striving for world/ global city status, cities prioritize their central business districts and invite the presence of powerful actors in the world economy. But global connectedness does not necessarily bring enhanced local living conditions. Urban inequality remains high in major metropolitan areas in both North and Latin America. Although globalization processes might not be the (only) source of this inequality - many problems find their origins some decades ago -, they can and do reproduce and magnify existing patterns of inequality, as the consequences of the global financial crisis and the 2008 food crisis show. 
Such occasional turmoil and persistent inequality occasions the presence of global actors responding to emergent needs of the "global immobile". This production of presence in American cities should receive considerable attention from those who are interested in governance for the flourishing of community throughout the hemisphere.

\section{References}

ALDERSON, A.; BECKFIELD, J.; SPRAGUE-JONES, J. Intercity relations and globalisation: the evolution of the global urban hierarchy. Urban Studies, v. 47 n. 9, p. 18991923, 2010.

AMEN, M.; ARCHER, K.; BOSMAN, M. Relocating global cities: from the center to the margins. Lanham: Rowman \& Littlefield Publishers, 2006.

ANHEIER, H.; GLASIUS, M.; KALDOR, M. (Ed.) Global civil society 2004/5. London: Sage, 2004.

BEAVERSTOCK, J.; SMITH, R.; TAYLOR, P. A roster of world cities. GaWC Research Bulletin, n. 5, 1999. Available at: <http://www.lboro.ac.uk/gawc/rb/rb5.html> Access in: 25 May 2010.

BEBBINGTON, A. NGOs and uneven development: geographies of development intervention. Progress in Human Geography, v. 28 n. 6, p. 725-745, 2004.

BORJA, J.; CASTELLS, M. Local and global: the management of cities in the information age. London: Earthscan, 1997.

BRENNER, N. Global cities, glocal states: global city formation and state territorial restructuring in contemporary Europe. Review of International Political Economy, v. 5, n. 1, p. 1-37, 1998.

BROWN, E.; CATALANO, G.; TAYLOR, P. Beyond world cities: Central America in a global space of flows. Area, v. 34 n. 2, p. 139-148, 2002.

BRUGMANN, J. Locating the 'Local Agenda': preserving public interest in the evolving urban world. In: MARCOTULLIO, P.; MCGRANAHAN, S. (Ed.). Scaling urban environmental challenges: from local to global and back. London: Earthscan, 2007. p. 331-354.
CALDER, K.; DE FREYTAS, M. Global political cities as actors in twenty-first century international affairs. SAIS Review, v. 29, n. 1, p. 79-97, 2009.

CASPARY, G. The energy sector in Latin America: key prospects, risks, and opportunities. Frankfurt: Deutsche Bank Research, 2007.

CASTELLS, M. Materials for an exploratory theory of the network society. British Journal of Sociology, v. 51 n. 1, p. 5-24, 2000a.

CASTELLS, M. The information age: economy, society and culture. The rise of the network society. 2nd ed. Oxford: Blackwell Publishing, 2000b. v. 1.

CASTELLS, M. Global governance and global politics. Political Science and Politics, v. 38, n. 1, p. 9-16, 2005.

DERUDDER, B. On conceptual confusion in empirical analyses of a transnational urban network. Urban Studies, v. 43, n. 11, p. 2027-2046, 2006.

DOUGLASS, M. From global intercity competition to cooperation for livable cities and economic resilience in pacific Asia. Environment and Urbanization, v. 14, n. 1, p. 53-68, 2002.

FLORIDA, R. The world is spiky. Atlantic Monthly, October, p. 48-51, 2005.

FLORIDA, R. Who's your city: how the creative economy is making where to live the most important decision of your life. New York: Basic Books, 2008.

FOREIGN POLICY. The 2008 Global Cities Index. 2008. Available at: <http://www.foreignpolicy.com/story/cms. php?story_id=4509\&print=1>. Access in: 6 Jan. 2010.

FREY, K.; PROCOPIUCK, M.; ROSA, A. Policy-oriented city networks in cyberspace: a methodological approach to the understanding of social and political articulations between cities based on the concept of policy web spheres. International Journal of Advanced Pervasive and Ubiquitous Computing, v. 2, n. 1, p. 18-37, 2010.

FRIEDMANN, J. The world city hypothesis. Development and Change, v. 17, n. 1, p. 69-83, 1986.

GLOBALIZATION AND WORLD CITIES - GAWC. A roster of world cities (Research Bulletin 5). Cities, v. 16, n. 6, p. 445-458, 1999. 
GLOBALIZATION AND WORLD CITIES - GAWC. The world according to GaWC 2008: classification of cities. 2008. Available at: <http://www.lboro.ac.uk/gawc/ world2008t.html>. Access in: 30 Sept. 2010.

GLASSMAN, J. From Seattle (and Ubon) to Bangkok: the scales of resistance to corporate globalization. Environment and Planning D: Society and Space, v. 20, n. 5, p. 513-533, 2002.

GRAHAM, S. The end of geography or the explosion of place? Conceptualizing space, place and information technology. Progress in Human Geography, v. 22, p. 165-185, 1998.

GRANT, R.; NIJMAN, J. Globalization and the corporate geography of cities in the less-developed world. Annals of the Association of American Geographers, v. 92, n. 2, p. 320-340, 2002.

GUGLER, J. (Ed.). World cities beyond the West: globalization, development and inequality. Cambridge: Cambridge University Press, 2004.

GUILLEN, M.; SUAREZ, S. Explaining the global digital divide: economic, political and sociological rivers of crossnational Internet use. Social Forces, v. 84, n. 2, p. 681$708,2005$.

HILL, R. Cities and nested hierarchies. International Social Science Journal, v. 56, n. 181, p. 373-384, 2004.

JAMES, P. Arguing globalizations: propositions towards and investigation of global formation. Globalizations, v. 2, n. 2, p. 193-209, 2005.

JAYNE, M. Globalization and third-tier cities: the European experience. In: ECKARDT, F; HASSENPFLUG, D. (Ed.). Urbanism and globalization. New York: Peter Lang, 2004.

KATZ, M. What is an American city? Dissent, p. 19-26, 2009.

KOCH, D.-J.; RUBEN, R. Spatial clustering of NGOs: an evolutionary economic geography approach. Papers in Evolutionary Economic Geography, v. 8, n. 14, p. 1-47, 2007.

KRÄTKE, S. City of talents? Berlin's regional economy, socio-spatial fabric, and worst-practice urban governance. International Journal of Urban and Regional Research, v. 28, n. 3, p. 511-529, 2004.
MANZANO, O.; MONALDI, F. The political economy of oil production in Latin America. Comment. Economía, v. 9, n. 1, p. 59-98, 2008.

NICHOLLS, W. The urban question revisited: the importance of cities for social movements. International Journal of Urban and Regional Research, v. 32, n. 4, p. 841-859, 2008.

OCAMPO, J. Latin America and the global financial crisis. Cambridge Journal of Economics, v. 33, p. 703-724, 2009.

PARNREITER, C. Megacities in the geography of global economic governance. Die Erde, v. 140, n. 4, p. 371-390, 2009.

PORTES, A.; ROBERTS, B. The free-market city: Latin American urbanization in the year of the neoliberal experiment. Studies in Comparative International Development, v. 40, n. 1, p. 43-82, 2005.

ROBERTS, B. Globalization and Latin American cities. International Journal of Urban and Regional Research, v. 29, n. 1, p. 110-123, 2005.

ROBINSON, J. Global and world cities: a view from of the map. International Journal of Urban and Regional Research, v. 26, n. 3, p. 531-554, 2002.

ROBINSON, J. Ordinary cities. London: Routledge, 2006. RODRIGUEZ, J.; MARTINEZ, G. Urbanization in Latin America and the Caribbean: experiences and lessons learned. In: MARTINE, G. et al. (Ed.) The new global frontier: urbanization, poverty and environment in the 21st century. London: Earthscan, 2008. p. 353-367.

ROITMAN, S.; PHELPS, N. Do gates negate the city? Gated communities contribution to the urbanisation of Suburbia in Pilar, Argentina. Urban Studies, v. 48, n. 16, p. 3487-3509, 2011.

SASSEN, S. The global city. Princeton: Princeton University Press, 1991.

SASSEN, S. From on concentration and centrality in the global city. In: KNOX, P.; TAYLOR, P. (Ed.). World cities in a world-system. Cambridge: Cambridge University Press, 1995.

SASSEN, S. New frontiers facing urban sociology at the millennium. British Journal of Sociology, v. 51, n. 1, p. 143-159, 2000. 
SASSEN, S. Territory, authority, rights: from medieval to global assemblages. Princeton: Princeton University Press, 2006.

SHATKIN, G. Global cities of the South: emerging perspectives on growth and inequality. Cities, v. 24, n. 1, p. 1-15, 2007.

SHORT, J. Global metropolitan: globalizing cities in a capitalist world. London: Routledge, 2004.

SHORT, J. et al. The dirty little secret of world cities research: data problems in comparative analysis. International Journal of Urban and Regional Research, v. 20, n. 4, p. 697-717, 1996.

SHORT, J. et al. From world cities to gateway cities. Extending the boundaries of globalization theory. City: Analysis of Urban Trends, Culture, Theory, Policy, Action, v. 4, n. 3, p. 317-338, 2000.

STEGER, M. Globalism: the new market ideology. Lanham: Rowman \& Littlefield, 2002.

SWYNGEDOUW, E. Globalisation or 'glocalisation'? Networks, territories and rescaling. Cambridge Review of International Affairs, v. 17, n. 1, p. 25-48, 2004.

TAYLOR, P. Worlds of large cities: Pondering Castells' space of flows. Third World Planning Review, v. 21, n. 3, p. iii-x, 1999.

TAYLOR, P. The new geography of global civil society: NGOs in the world city network. Globalizations, v. 1, n. 2, p. 265-277, 2004a.

TAYLOR, P. World city network: a global urban analysis. London: Routledge, 2004b.

TAYLOR, P. Leading world cities: empirical evaluations of urban nodes in multiple networks. Urban Studies, v. 42, n. 9, p. 1593-1608, 2005.

TAYLOR, P.; LANG, R. U.S. cities in the 'World City Network'. The Brooking Institution Survey Series, p. 1-17, 2005.
TAYLOR, P. et al. Measuring the world city network: new results and developments. GaWC Research Bulletin 300, 2010. Available at: <http://www.lboro.ac.uk/gawc/ rb/rb300.html>. Access in: 15 June 2010.

TEPLOVA, T. World economy trends and their implication for the city of Calgary. Ottawa: Canadian Policy Research Networks Inc, 2006. Available at: <http:// www.uquebec.ca/observgo/fichiers/17943_GLR1.pdf> Access in: 10 Sept. 2010.

TOLY, N. et al. New maps, new questions: global cities beyond the advanced producer and financial services sector. Globalizations, v. 9, n. 2, p. 289-306, 2012.

UNDESA. World urbanization prospects: the 2009 revision. Map 1 Urban agglomerations in 2009. 2010. Available at: <http://esa.un.org/unpd/wup/maps_1_2009.htm>. Access in: 8 Sept. 2010.

UN-HABITAT. State of the world's cities 2006/7: the millennium development goals and urban sustainability. 30 years of shaping the Habitat agenda. London: Earthscan, 2006.

UN-HABITAT. State of the world's cities 2010/2011: bridging the urban divide. London: Earthscan, 2008.

UNION OF INTERNATIONAL ASSOCIATIONS. Yearbook of International Organizations: guide to global and civil society networks 2006/2007. Statistics, visualizations and patterns. München: K.G. Saur, 2006. v. 5.

VAN KEMPEN, R. Divided cities in the 21st century: challenging the importance of globalisation. Journal of Housing and Built Environment, v. 22, n. 1, p. 13-31, 2007.

VINE, E. An international survey of the energy service company (ESCO) industry. Energy Policy, v. 33, n. 5, p. 691-704, 2005.

Received: $03 / 26 / 2012$

Recebido: 26/03/2012

Approved: 04/19/2012

Aprovado: 19/04/2012 